\title{
Comparison of Hepatic and Nephric Total Mercury Concentrations Between Feral and Ranch American Mink (Neovison vison) from Northwestern Poland
}

\author{
Elzbieta Kalisinska • Halina Budis • \\ Natalia Lanocha • Joanna Podlasinska • \\ Ewa Jedrzejewska • Danuta I. Kosik-Bogacka
}

Received: 5 September 2011/ Accepted: 1 February 2012/Published online: 23 February 2012

(C) The Author(s) 2012. This article is published with open access at Springerlink.com

\begin{abstract}
For many years the American mink (Neovison vison) has been used in North America (where it originates from) as a sensitive indirect bioindicator in assessing the degree of mercury $(\mathrm{Hg})$ contamination in terrestrial ecosystems. The aim of this paper was the determination of total concentrations of $\mathrm{Hg}$ in the liver and kidneys of feral and ranch mink from the Warta Mouth National Park (WMNP) and from farms located in northwestern Poland, for comparison with similar data on American mink from North America. In road-killed feral mink from the WMNP, the mean concentrations were 11.8 and $14.1 \mathrm{mg} / \mathrm{kg}$ dry weight in the liver and kidney, respectively. Mean $\mathrm{Hg}$ concentrations in feral mink were from 240 to 90 times higher in these two respective tissues than in ranch mink. The feral mink from northwestern Poland had concentrations of hepatic and nephric $\mathrm{Hg}$ similar to the highest concentrations that have been recorded over the past several decades in wild American mink from certain areas of Canada and the USA.
\end{abstract}

E. Kalisinska $\cdot$ H. Budis $\cdot$ N. Lanocha .

D. I. Kosik-Bogacka ( $\square)$

Department of Biology and Medical Parasitology,

Pomeranian Medical University,

Powstancow Wielkopolskich 72,

70-111 Szczecin, Poland

e-mail: kodan@pum.edu.pl

J. Podlasinska

Department of Environmental Management and Protection,

Western Pomeranian University of Technology, Słowackiego 17,

71-374 Szczecin, Poland

E. Jedrzejewska

Warta Mouth National Park, Chyrzyno 1, 69-113 Gorzyca,

Poland
Keywords American mink - Total mercury · Kidney · Liver · Bioindicator · Poland

American mink (Neovison vison, formerly Mustela vision) in its homeland, North America, has been used for decades as a sensitive indirect bioindicator for the assessment of mercury contamination of terrestrial ecosystems. Its diet consists largely of fish caught in inland waters, and birds and mammals in the vicinity of rivers and lakes (Carmichael and Baker 1989; Evans et al. 2000; Bartoszewicz and Zalewski 2003).

The liver and kidney of aquatic and semiaquatic predatory vertebrates accumulate methylmercury, the most toxic and widespread form of mercury $(\mathrm{Hg})$, which is subject to biomagnification in aquatic food chains. It tends to reach its highest concentrations in piscivorous birds and mammals, including the mink (Wobeser 1976; Osowski et al. 1995; Scheuhammer et al. 2007). This species belongs to a group of fur-bearing mammals, and therefore in different parts of the world (including Europe) is farmed for fur. More than 50 years ago in Europe (including the territories of the former Soviet Union on the eastern Polish border), ranch mink were deliberately released into the wild. Their descendants, as well as those of mink that had escaped from farms, currently live in their respective habitats in many parts of the continent, including Poland (Lariviere 1999; Bartoszewicz and Zalewski 2003; Brzezinski et al. 2010). In western Poland, including Slonsk Reserve (presently part of the Warta Mouth National Park), American mink did not first appear until the early 1990s (Bartoszewicz and Zalewski 2003).

The aim of this study was to examine the concentrations of mercury in the bodies of road-killed feral mink from the Warta Mouth National Park (Park Narodowy Ujscie Warty) 
and ranch mink from a farm located in northwestern Poland, for the purpose of comparing their liver and kidney levels, and to assess the levels of contamination in these organs relative to levels reported in North American mink.

\section{Materials and Methods}

The area of the Warta Mouth National Park (WMNP, 8,074 ha) is periodically inundated by the waters of the Warta and Odra Rivers (Polish/Czech: Odra; German: Oder). The Odra River is the second largest river in Poland and its greatest eastern tributary, the Warta, joins near the town of Kostrzyn $\left(52^{\circ} 35^{\prime} \mathrm{N} ; 14^{\circ} 40^{\prime} \mathrm{S}\right)$ in western Poland (Fig. 1).

The study was carried out on six feral mink (N. vison) found dead on the roads of WMNP in 2009-2011. From these specimens, we collected 6 livers and 8 kidneys for chemical analysis as some organs were damaged. We also examined both the liver and kidneys of 7 ranch mink obtained from one of the farms in northwestern Poland in 2007. Carcasses were kept in a freezer at $-20^{\circ} \mathrm{C}$. After dissection of the thawed carcasses, samples of the liver and kidney (about $10 \mathrm{~g}$ each) used for the determination of $\mathrm{Hg}$ were dried at $55^{\circ} \mathrm{C}$. Within $4-6$ weeks, the samples were weighed three times to constant weight (to $0.1 \mathrm{mg}$, Sartorius BP221S balance), which made it possible to determine weight-based water content. Subsequently, the samples were crushed in an agate mortar. Total $\mathrm{Hg}$ concentrations were determined using atomic absorption spectroscopy (AAS) at the Department of Environmental Management and Protection, Western Pomeranian University of
Technology in Szczecin. The assays were run in an AMA 254 mercury analyser (Altach Ltd, Czech Republic) in accordance with previously described methods (Kalisinska et al. 2009). The apparatus has a detection limit of $0.01 \mathrm{ng}$ and a detection range of 0.05-600 ng. The AMA 254 analyzer permits the determination of $\mathrm{Hg}$ in biological samples without having to perform prior mineralization in wet conditions. Mercury concentrations were referred to both dry weight (dw) and wet weight (ww) of the respective organ. The analytical procedures used were checked by determining $\mathrm{Hg}$ concentrations in samples of two reference materials: bovine liver (BCR 186, Commission of the European Countries, Community Bureau of References-BCR) and fish tissue (IAEA 407, International Atomic Energy Agency-IAEA, Austria).

In addition, the percentage of water content was determined by gravimetric method in the studied organs. Intragroup and inter-group comparisons of mean hepatic and nephric mercury concentrations were performed using a Student $t$ test.

\section{Results and Discussion}

The mean water content in the liver and kidney of all studied mink was $69 \%$ and $73 \%$, respectively. Our analysis of certified reference materials yielded total $\mathrm{Hg}$ concentrations of $1.96 \pm 0.16$ and $0.237 \pm 0.002 \mathrm{mg} / \mathrm{kg} \mathrm{dw}$ for BCR 186 $(\mathrm{n}=6)$ and IAEA $407(\mathrm{n}=5)$, respectively. Corresponding values from the suppliers were 1.97 and $0.222 \mathrm{mg} / \mathrm{kg} \mathrm{dw}$, respectively. The recovery rates were $99.2 \%$ and $107 \%$ for BCR 186 and IAEA 407, respectively.
Fig. 1 Location of study areas in western Poland

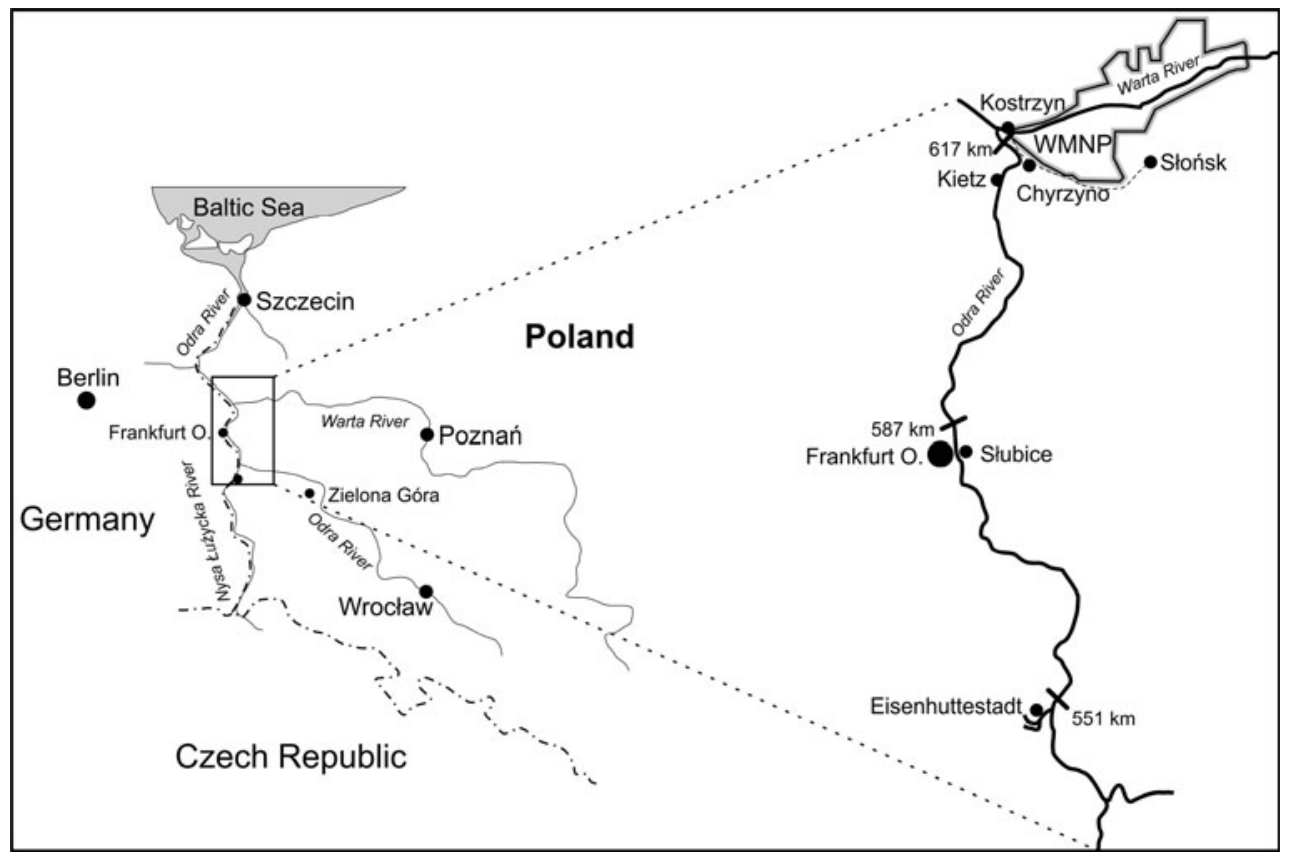


In feral mink from the WMNP the mean concentrations of $\mathrm{Hg}$ were similar in the liver and kidney, the organs that play a key role in the detoxification of $\mathrm{Hg}$-about 12 and $14 \mathrm{mg} / \mathrm{kg} \mathrm{dw}$, respectively (Student test $t=0.910$, $p>0.381)$. In the feral mink, the mean concentration of $\mathrm{Hg}$ in the kidney was about $20 \%$ higher than in the liver, while statistically confirmed differences between the two types of samples analyzed were not found. Maximum concentrations of hepatic and nephric $\mathrm{Hg}$ reached $\sim 21$ and $\sim 19 \mathrm{mg} / \mathrm{kg} \mathrm{dw}$, which corresponds to 6.5 and $5.1 \mathrm{mg} / \mathrm{kg}$ ww, respectively (Table 1). To date, the baseline concentration of $\mathrm{Hg}$ in the liver and kidney of the American mink, which would reflect the geochemical background northwestern Poland, has not been determined definitively. Osowski et al. (1995) studied the concentration of mercury in the kidneys of several populations of American mink from Georgia, North Carolina and South Carolina (USA). In the 1960s, a decline in this species was observed. The Piedmont Mountains population had a stable size and was treated as a reference group, known as the Piedmont reference mink (PR). In this PR group, the mean nephric mercury level was $0.527 \mathrm{mg} / \mathrm{kg}$ ww ( $\sim 2.11 \mathrm{mg} / \mathrm{kg} \mathrm{dw}$ ), and this value was taken as reflecting the geochemical background. Carmichael and Baker (1989), on the basis of various papers, suggested "normal" concentrations of mercury in mink liver were $\leq 2 \mathrm{mg} / \mathrm{kg}$ ww (about $6 \mathrm{mg} / \mathrm{kg} \mathrm{dw}$ ).

The main anthropogenic sources of heavy metals (including $\mathrm{Hg}$ ) in the Odra River course are the Upper and Lower Silesian coal-mining and metallurgical districts. Also important sources of heavy metal pollutions are German cities, Eisenhuttenstadt and Frankfurt O. (Oder), where major industrial enterprises are located, e.g. the steelworks of the Eisenhuttenkombinat-Ost (Muller et al. 2002). Moreover, the contamination of the confluence of the Warta and Odra rivers with mercury may have been caused by a celulose-paper production plant in Kostrzyn (founded in the 1930s). In 2002, the concentration of $\mathrm{Hg}$ in sediments of the Odra ranged from 0.35 to $1.32 \mathrm{mg} / \mathrm{kg}$ in Eisenhuttestadt and from 0.28 to $1.49 \mathrm{mg} / \mathrm{kg}$ in Kostrzyn (Fig. 1) (Boszke et al.
2004). In 2009, results from PGEMO of bottom sediments showed $0.25 \mathrm{mg} \mathrm{Hg} / \mathrm{kg}$ in the Warta River near Kostrzyn (www.gios.gov.pl). The sediments were classified as weakly and moderately polluted, respectively (Bojakowska and Sokolowska 1998). According to US sediment quality guidelines (SQGs) mercury should not exceed $0.2 \mathrm{mg} / \mathrm{kg} \mathrm{dw}$ (MacDonald et al. 2000). In relation to the quoted value of SQGs used in ecotoxicological studies, the concentration of $\mathrm{Hg}$ in sediments of the Warta River in 2009 was $25 \%$ higher, and in earlier years many times higher for both the sediments of the Odra and Warta.

Interesting observations on the difference in hepatic $\mathrm{Hg}$ concentrations in mink from various parts of the Great Lakes (Quebec) were made by Martin et al. (2011). Canadian mink, which were trapped in large riverine marshes, had the highest hepatic $\mathrm{Hg}$ level $(15.3 \mathrm{mg} / \mathrm{kg} \mathrm{dw})$ in comparison to individuals collected in smaller tributaries/creeks or drainage ditches of the basin $(2.3 \mathrm{mg} / \mathrm{kg} \mathrm{dw})$ (Table 2). Our feral mink were found in areas regularly flooded by the Odra and Warta rivers. From this, it appears that feral mink collected from the WMNP had elevated total $\mathrm{Hg}$ levels in comparison to the suggested geochemical background level for Hg. Recently, Bowman et al. (2012) drew attention to the differences in mercury concentrations in the liver from wild and feral mink collected in Ontario (Quebec) in 1998-2006. Among 133 genotyped individuals of American mink, the authors found 9\% domestic, $10.5 \%$ hybrid and $80.5 \%$ wild genotypes, respectively. After exclusion of domestic mink from a general pool of specimens, wild mink contained a mean of $3.91 \mathrm{mg} / \mathrm{kg}$ dw total $\mathrm{Hg}$ in their liver, compared to a mean of $1.33 \mathrm{mg} / \mathrm{kg} \mathrm{dw}$ in domestic mink. In comparison to the hepatic $\mathrm{Hg}$ concentration of wild mink from Canada, Polish feral mink had over three times higher mercury levels $(\sim 12 \mathrm{~m} / \mathrm{kg} \mathrm{dw})$. However, among the feral mink in our study there was a single individual (excluded from statistical analysis), which had distinctly lower concentrations of $\mathrm{Hg}$ in both the liver and kidney. These concentrations were much more similar to the values indicated in the organs of Polish ranch mink (Table 1). It seems, therefore, that in an indirect assessment

Table 1 Hepatic and nephric mercury concentrations ( $\mathrm{mg} / \mathrm{kg} \mathrm{dw}$ and ww) in feral and ranch American mink from Poland (AM-arithmetic mean; SD-standard deviation)

\begin{tabular}{|c|c|c|c|c|c|c|c|}
\hline \multicolumn{2}{|c|}{ American mink } & \multicolumn{3}{|c|}{ Liver } & \multicolumn{3}{|c|}{ Kidney } \\
\hline & & $\mathrm{n}$ & $\mathrm{dw}$ & ww & $\mathrm{n}$ & $\mathrm{dw}$ & ww \\
\hline \multirow[t]{3}{*}{ Feral mink } & $\mathrm{AM} \pm \mathrm{SD}$ & 6 & $11.8 \pm 6.21$ & $3.65 \pm 1.93$ & 8 & $14.1 \pm 3.31$ & $3.81 \pm 0.89$ \\
\hline & $\min -\max$ & & $3.28-20.9$ & $1.02-6.47$ & & $9.34-19.0$ & $2.52-5.12$ \\
\hline & & $1^{\mathrm{a}}$ & 0.11 & 0.03 & 1 & 0.31 & 0.08 \\
\hline \multirow{2}{*}{$\begin{array}{r}\text { Ranch } \\
\text { mink }\end{array}$} & $\mathrm{AM} \pm \mathrm{SD}$ & 7 & $0.05 \pm 0.02$ & $0.01 \pm 0.01$ & 7 & $0.15 \pm 0.11$ & $0.04 \pm 0.03$ \\
\hline & $\min -\max$ & & $0.04-0.08$ & $0.00-0.03$ & & $0.06-0.37$ & $0.02-0.10$ \\
\hline
\end{tabular}

a specimen that was probably a recently escaped ranch mink 
Table 2 Comparison of mean mercury concentrations in the liver and kidney of feral American mink from Poland and wild mink from North America (mg/kg dw and ww; in the dw and ww conversions it was assumed that both the liver and kidney contain $70 \%$ water; LFR, Lower Fraser River; WMNP, Warta Mouth National Park)

\begin{tabular}{|c|c|c|c|c|c|}
\hline \multicolumn{2}{|l|}{ Liver } & \multicolumn{2}{|c|}{ Kidney } & \multirow[t]{2}{*}{ Country and years } & \multirow[t]{2}{*}{ Source } \\
\hline $\mathrm{dw}$ & ww & $\mathrm{dw}$ & ww & & \\
\hline 11.8 & 3.65 & 14.1 & 3.81 & Poland, WMNP, 2009-2011 & This study \\
\hline 1.33 & 0.40 & - & - & USA, South Carolina, 1987-1988 & Carmichael and Baker 1989 \\
\hline- & - & 7.47 & 2.24 & USA, North and South Carolina, 1989-1991 & Osowski et al. 1995 \\
\hline 2.87 & 0.86 & - & - & USA, Main, 2001 & Bank et al. 2007 \\
\hline 14.57 & 4.37 & 7.30 & 2.19 & Canada, Québec, 1993-1995 & Fortin et al. 2001 \\
\hline 5.10 & 1.53 & 3.67 & 1.01 & Canada, Ontario, 1994 & Evans et al. 2000 \\
\hline 12.6 & $3.79^{\mathrm{a}}( \pm 4.32)$ & - & - & Canada, Ontario, 1998-2006 & Bowman et al. 2012 \\
\hline $0.99^{\mathrm{a}}( \pm 0.36)-7.31( \pm 1.52)$ & 0.30 & - & - & Canada, Great Lakes, 1998-2006 & Martin et al. 2011 \\
\hline 3.07 & 0.92 & 2.20 & 0.66 & Canada, Yukon, 2001-2003 & Gamberg et al. 2005 \\
\hline 4.62 & 1.37 & 3.13 & 0.94 & $\begin{array}{l}\text { Canada, British Columbia, } \\
\text { Lower Fraser River, 1990-1996 }\end{array}$ & Harding et al. 1998 \\
\hline
\end{tabular}

${ }^{\mathrm{a}}$ mean $\pm \mathrm{SE}$

of environmental contamination with mercury, one should exactly identify individual specimens included in the chemical analysis, as recently escaped ranch mink from farms (or domestic mink) may cause underestimations of contamination in the study area.

In native wild specimens of the American mink, nephric and hepatic concentrations of $\mathrm{Hg}$ have assumed very different values, depending on the region of North America, as well as the degree and source of mercury contamination. Over the last two decades, in North American trapped mink, the mean liver and kidney concentrations, have usually been between $<5$ and $10 \mathrm{mg} / \mathrm{kg}$ dw (Table 2).

Maximum concentrations of $\mathrm{Hg}$ in the liver and kidney of our ranch mink did not exceed 0.09 and $0.40 \mathrm{mg} / \mathrm{kg} \mathrm{dw}$, respectively. In the ranch mink the mean concentration of $\mathrm{Hg}$ in the kidney was almost three times higher than in the liver $(p<0.04)$. Similarly, Wobeser (1976) and Stejskal et al. (1989) either did not detect mercury in the liver and kidney in ranch mink, or its concentrations were low $(<0.7 \mathrm{mg} / \mathrm{kg} \mathrm{ww}$ or $<2.3 \mathrm{mg} / \mathrm{kg} \mathrm{dw})$.

Comparative analysis showed statistically confirmed differences in hepatic $\mathrm{Hg}$ concentrations between escaped ranch mink and feral mink $(p<0.03)$, and escaped ranch mink and ranch mink $(p<0.01)$.

In summary, feral mink from the Warta Mouth National Park, when compared with ranch mink from northwestern Poland, had mean hepatic and nephric total $\mathrm{Hg}$ concentrations (dw) that were on average about 240 and 90 times greater than their respective concentrations in ranch mink. Due to the small number of samples tested, it is desirable to continue these studies on larger and more diverse materials to allow better assessment of the situation of degree of $\mathrm{Hg}$ concentration in various piscivorous birds and mammals that inhibit the WMNP, including American mink and protected Eurasian otter. This study is one of the first in Europe to describe the use of feral American mink as bioindicators to indirectly assess of mercury pollution in the environment.

Open Access This article is distributed under the terms of the Creative Commons Attribution License which permits any use, distribution, and reproduction in any medium, provided the original author(s) and the source are credited.

\section{References}

Bank MS, Burgess JR, Evers DC, Loftin CS (2007) Mercury contamination of biota from Acadia National Park, Maine: a review. Environ Monit Assess 126:105-115

Bartoszewicz M, Zalewski A (2003) American mink Mustela vison diet and predation on waterfowl in the Słonsk Reserve, western Poland. Folia Zool 52:225-238

Bojakowska I, Sokolowska G (1998) Geochemical purity of water sediments. Przegl Geol 46:49-54 (in Polish)

Boszke L, Sobczynski T, Głosinska D, Kowalski A, Siepak J (2004) Distribution of mercury and other heavy metals in bottom sediments of middle part Odra River (Germany/Poland). Pol J Environ Stud 13:495-502

Bowman J, Kidd AG, Martin PA, McDaniel TV, Nituch LA, SchulteHostedde AI (2012) Testing for bias in a sentinel species: contaminants in free-ranging domestic, wild, and hybrid mink. Environ Res 112:77-82

Brzezinski M, Marzec M, Zmihorski M (2010) Spatial distribution, activity, habitat selection of American mink (Neovison vison) and polecats (Mustela putorius) inhabiting the vicinity of eutrophic lakes in NE Poland. Folia Zool 59:183-191

Carmichael DB, Baker OE (1989) Pesticide, PCB and heavy metal residues in South Carolina mink. Proc Annu Conf Southeast Assoc Fish Wildl Agencies 43:444-451 
Evans RD, Addison EM, Villeneuve JY, MacDonald KS, Joachim DG (2000) Distribution of inorganic and methylmercury among tissues in mink (Mustela vison) and otter (Lutra canadensis). Environ Res Sect A 84:133-139

Fortin C, Beauchamp D, Dansereau M, Larivier N, Belanger D (2001) Spatial variation in mercury concentrations in wild mink and river otter carcasses from the James Bay Territory, Quebec, Canada. Arch Environ Contam Toxicol 40:121-127

Gamberg M, Bolia G, Stern G, Roach P (2005) Cadmium, mercury and selenium concentrations in mink (Mustela vison) from Yukon, Canada. Sci Total Environ 351-352:523-529

Harding L, Harris ML, Elliott JE (1998) Heavy and trace metals in wild mink (Mustela vison) and river otter (Lutra canadensis) captured on rivers receiving metals discharges. Bull Environ Contam Toxicol 61:600-607

Kalisinska E, Lisowski P, Salicki W, Kucharska T, Kavetska K (2009) Mercury in wild terrestrial carnivorous mammals from north-western Poland and unusual fish diet of red fox. Acta Theriol 54:345-356

Lariviere S (1999) Mustela vison. Mamm Spec 608:1-9

MacDonald DD, Ingersoll CG, Berger TA (2000) Development and evaluation of consensus-based sediment quality guidelines for freshwater ecosystems. Arch Environ Contam Toxicol 39:20-31
Martin PA, McDaniel TV, Hughes KD, Hunter B (2011) Mercury and other heavy metals in free-ranging mink of the lower Great Lakes basin, Canada, 1998-2006. Ecotoxicology 20:1701-1712

Muller A, Heininger P, Wessels M, Pelzer J, Grunwald K, Pfitzner S, Berger M (2002) Contaminant levels and ecotoxicological effects in sedimentation of the River Odra. Acta Hydrochim Hydrobiol 30:244-255

Osowski SL, Brewer LW, Baker OE, Cobb GP (1995) The decline of mink in Georgia, North Carolina, and South Carolina: the role of contaminants. Arch Environ Contam Toxicol 29:418-423

Scheuhammer AM, Meyer MW, Sandheinrich MB, Murray MW (2007) Effects of environmental methylmercury on health of wild birds, mammals, and fish. Ambio 36:12-18

Stejskal S, Aulerich RJ, Slanker MR, Braselton WE, Lehning EJ, Napolitano AC (1989) Element concentrations in livers and kidneys of ranch mink. J Vet Diagn Invest 1:343-348

Wobeser G (1976) Mercury poisoning in mink. J Wildl Dis 12: $335-340$ 